\title{
The United States of America's Foreign Policy towards Jordan During (George H. W. Bush) Administration1989- 1993 (A Case Study of the Iraqi War on Kuwait)
}

Ala Mohammad Alkhawaldeh \& Suyatno Ladiqi

To Link this Article: http://dx.doi.org/10.6007/IJARBSS/v11-i3/8969

DOI:10.6007/IJARBSS/v11-i3/8969

Received: 08 January 2021, Revised: 10 February 2021, Accepted: 28 February 2021

Published Online: 26 March 2021

In-Text Citation: (Alkhawaldeh \& Ladiqi, 2021)

To Cite this Article: Alkhawaldeh, A. M., \& Ladiqi, S. (2021). The United States of America's Foreign Policy towards Jordan During (George H. W. Bush) Administration1989-1993 (A Case Study of the Iraqi War on Kuwait). International Journal of Academic Research in Business and Social Sciences, 11(3), 1263-1269.

Copyright: (c) 2021 The Author(s)

Published by Human Resource Management Academic Research Society (www.hrmars.com)

This article is published under the Creative Commons Attribution (CC BY 4.0) license. Anyone may reproduce, distribute, translate and create derivative works of this article (for both commercial and non-commercial purposes), subject to full attribution to the original publication and authors. The full terms of this license may be seen at: http://creativecommons.org/licences/by/4.0/legalcode

Vol. 11, No. 3, 2021, Pg. 1263 - 1269

Full Terms \& Conditions of access and use can be found at http://hrmars.com/index.php/pages/detail/publication-ethics 


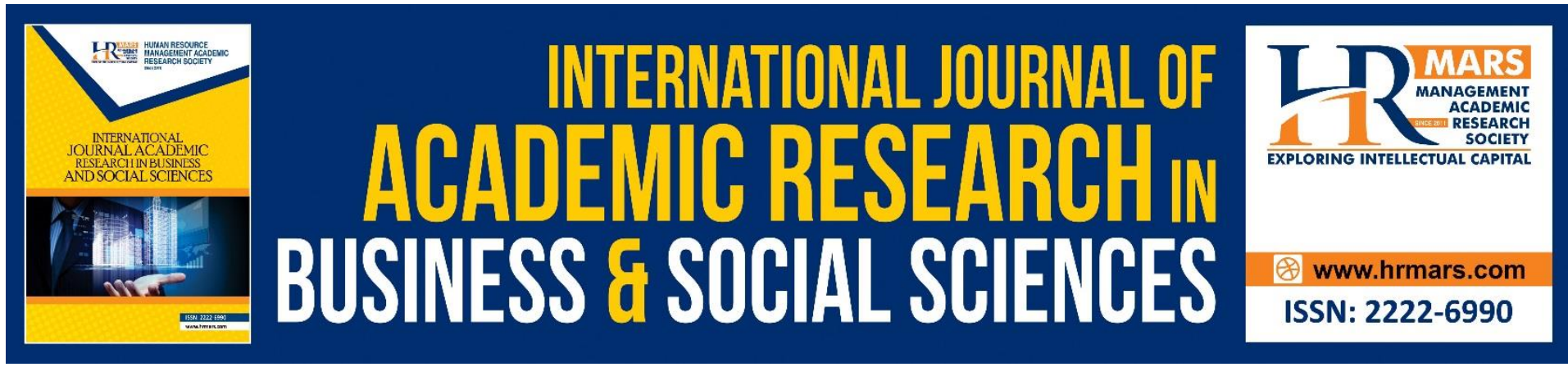

\title{
The United States of America's Foreign Policy towards Jordan During (George H. W. Bush) Administration1989-1993 (A Case Study of the Iraqi War on Kuwait)
}

\author{
Ala Mohammad Alkhawaldeh \& Suyatno Ladiqi \\ Faculty of Law and International Relations (FUHA) Universiti Sultan Zainal Abidin (UniSZA) \\ Gong Badak Campus 21300 Kuala Nerus Terengganu Darul Iman. \\ Email: ala.alkhawaldeh@yahoo.com, yatno.ladiqi@gmail.com
}

\begin{abstract}
This paper examines the United States of America's foreign policy towards Jordan during the administration (George H. W. Bush) (1989-1993). The change occurred in the United States foreign policy towards Jordan due to Jordan's position opposing the United States of America towards an Iraq war. Jordanian-American connections were disrupted because of that war when Jordan took a stand of opposition to the United States of America, influencing political and economic relations between them. So Jordan is the only one affected by that war. The study is conducted as qualitative research. The study reached the following results: On the political side, the Iraqi war on Kuwait led to a tense relationship between Jordan and the United States of America due to Jordan's refusal to enter the coalition against Iraq under the United States' leadership America. The Jordanian popular position in Iraq's support in that war led to Jordanian pressure not to accept that alliance and this position. The United States of America has pressured the Gulf States to cut ties with Jordan. On the economic side of every political event with economic consequences and the Jordanian political position towards that war, Jordanian relations with the Gulf countries were cut off due to American pressure. Also, oil supplies from Iraq, which were taken at symbolic prices, were cut off. Hundreds of thousands of expatriates in the Gulf countries returned to Jordan, also reduced American aid to Jordan and closure the port of Aqaba. Those pressures led to a drop in the gross domestic product by $8 \%$, slowing economic growth, and an increase in the unemployment rate to $30 \%$ and poverty to $33 \%$.
\end{abstract}

Keywords: Foreign Policy, Iraq War, the United States, the First Gulf War

\section{Introduction}

The United States' foreign policy began to look at rapprochement with the Hashemite Kingdom of Jordan since the Cold War. The United States established diplomatic relations with the Hashemite Kingdom of Jordan on January 31, 1949. Since then, the United States has recognized Jordan's leadership's unique role in fostering stability, promoting democracy, and transformation in the Middle East. Moreover, the United States and Jordan have similar 
dreams, priorities, and interests regarding establishing a just, inclusive, and long-term Concord in the district.

Jordan is also influenced by its strategic surroundings and international affairs, as well as factors and influences emerging from its geographical, demographic, and economic circumstances, such as foreign assistance, the reality of national wealth, social, and economic changes taking place through the restructuring process, and this is revealed in the social and political configuration of Jordanian society.

\section{Significance of the Study}

This study is expected to be significant in broad dimensions. First, it will provide some literature that contributes to the body of knowledge by looking at United States foreign policy toward Jordan. The research will also shed light on the connection between the United States and Jordan from aspects (political, economic). This research is expected to be a guide to future studies in the area. Finally, this new study attempts to uncover the United States' foreign policy towards Jordan from a deeper level in all aspects to obtain the correct results.

\section{Research Methodology}

The study is conducted as a qualitative research

The study will adopt secondary sources of data to achieve its purpose. Secondary data, which involves journals, thesis, books.

\section{Political Side}

Iraq entered Kuwait during the presidency of George H. W. Bush (1989-1993) and King Hussein bin Talal's rule. The conquest of Kuwait on August 2, 1990, two days' campaign by Iraq was contrary to Kuwait, which culminated in a seven-month Kuwait invasion. This invasion and Iraq's failure to pull out from Kuwait by a cutoff date set by the United Nationsled to military action by an alliance of powers led by the United States. The second Gulf War led to Iraqi forces' eviction from Kuwait, with the Iraqis setting fire to 600 Kuwaiti oil wells as part of their withdrawal. (Browne, 2003; O'Connell, 1990; Berger, 1991).

The Jordanian position on Iraq's annexation of Kuwait, in light of the opposition of all Arab countries to Iraq, Jordan stood with Iraq in that war, where King Hussein supported a number of Arab meetings to resolve the issue within the Arab framework and the non-interference of foreign forces in an Arab land, to know King Hussein of the West's greed for resources Arabic. Jordan refused to join the US-led coalition when Iraq invaded Kuwait. On the other hand, Jordan demanded Iraq's withdrawal and retained its recognition of Kuwait's al-Sabah government, rejecting Iraq's annexation claim. Even though many Jordanians offered to defend Iraq, Jordan's military stayed unbiased and refused to fight alongside Iraq's battalion. Critics interpreted Jordan's role in 1990 as favouring Iraq. It was claimed in Western capitals that Jordan has aligned itself with Saddam Hussein and opposed its long-time allies in the West, as well as pro-Western administrations in the world of Arab. Many supporters of Jordan saw Jordan's strategy as an embodiment of a stable position. Both countries, however, perceived Jordan's depth susceptibility both locally and provincially and that there is no other option than high costs (Mason, 2011; Ryan, 2000).

Economic issues and domestic politics, including Jordan's fledgeling "democratization" initiative, affected Jordan's position in the course of a second Gulf War. In 1989, the Hashemite government embarked on a constitutional liberalization program in response to protests triggered by IMF rigour action. This included loosening press restrictions and 
enabling legislative elections of which antagonism Islamist candidates performed well. Jordan's parliament and people took a clear and unambiguous pro-Iraq view than the monarchy for the Gulf crisis period. Various street protests, articles in newly founded newspapers and magazines, and speeches on the parliament's floor revealed widespread public support for Saddam Hussein. (Ryan, 2000; Mason, 2011).

Contrary to Iraq, the international-led bombing operation commenced, the Jordanian administration articulated greater concern for Iraqi civilians. Jordanian truck drivers were killed by an American airstrike on the Baghdad-Amman highway on February 6, 1991, prompting King Hussein to make a powerful speech to his government. In his speech, the King slammed the US-led coalition's war on Iraq, proclaiming that the coalition's campaign was "contrary to all Arabs and Muslims but not against Iraq alone." Furthermore, he alleged that the Western cooperation intended to "abolish Iraq and restructure the region in such a way that will be more harmful to our people than the Sykes-Picot agreement," implying that coalition troops were attempting to declare foreign hegemony in the Middle East. This speech prepared the US to suspend assistance to Jordan and promised to review potential aid plans. "Even though the United State 'inherently upsets with Jordanian King Hussein's harsh condemnation of the Iraq war. The choices available to Hussein are not 'specifically appealing,' and it is imperative to maintain relations with the King," Secretary of State James A. Baker III. (Ryan, 2000; Frantzman,2010; Mason, 2011).

After three days, President Bush sent King Hussein a close, punitive letter expressing his displeasure: I will not suppress my abysmal dissatisfaction with your discourse on February 6 . I wasn't prepared to read such a venomous assault on the multinational coalition's motives and actions in redemptive Kuwait.... your words absolve Saddam Hussein of the most horrific and heinous crime committed against an Arab country by another Arab in modern history... So be it if we disagree on these points. However, we must recognize that the media, political deportment that distances Jordan from international and Arab harmony has severely harmed Jordan's international assistance chances. If I remain cautious in my public statements about your allegations, it is only because I continue to respect, however unrequitedly, the well-being and stability of your country. (Ashton, 2008).

\section{Economic Side}

Every political event has economic consequences for the country. The Iraqi invasion of Kuwait in 1990 had economic consequences for Jordan as a result of Jordan's political stance on this invasion. It was explained previously, where the interdependence between Jordan and Iraq was extensive during the first Gulf War, where most Iraqi exports are exported through the Jordanian port of Al- Aqaba, and it reaches more than $75 \%$ of their exports.

Jordan complied with UN Security Council Resolution 661, which termed for the implementation of an economic trade embargo on Iraq immediately following the Iraqi occupation of Kuwait. The United Nations sanctions have had a huge effect on Jordan's wellbeing and economy, as Iraq has been Jordan's main trading partner for the past ten years (Swaidan \& Nica,2002). Jordan's diplomatic stance on the crisis and its later unwillingness to enforce UN trade sanctions against Iraq enable the US to be closed to the Gulf of Aqaba, which is its only port exit to the outside world. After the Gulf Crisis of 1990-1991, which lasted for two weeks (Al Sarhan,2016).

Furthermore, the UN resolution directly affected key Jordanian economic segments such as agriculture, industry, and transportation, primarily serving Iraq. In November 1990, the Amman Chamber of Commerce estimated that the trade embargo has already made Jordan 
lose $\$ 2$ billion, which keep on rising. They estimated it to hit $\$ 3.6$ billion in 1991, according to the same source. Furthermore, before the resolution, Iraq supplied Jordan with 80 per cent of its oil at downsized prices. Jordan needs to import oil at market prices as a result of the sanctions. (Swaidan \& Nica, 2002).

Iraq was reliant on Jordan as a path for importing and exporting vital goods. Jordan's port of Aqaba handled millions of tons of goods for Iraq per year, and this sector of the economy has been steadily expanding before trade restrictions. The port's importations dropped from 6.2 million tons in 1989 to 3.2 million tons in 1990 and 1.5 million tons in 1991 . To a lesser degree, exports had suffered from 10 million tons in 1989 to 8.9 million in 1990 to 7.7 million in 1991. (Swaidan \& Nica, 2002).

Numerous shipping trips were suspended due to trade embargoes, and the number of ships that arrived in Aqaba fell from 2,583 in 1988 to 2,075 in 1991. This made obtaining products for local industry and agriculture more challenging and time-consuming for Jordan and affecting Jordanian exports. Every year, allied warships evaluate thousands of ships. Many shipments belonging to Jordanian business people with business links to Iraq were inverted, even though they were intended for domestic use. Jordan's phosphate and potassium exports were also disrupted by the port of Aqaba's closure. (Mofid, 1990).

The Gulf War afflicted forty countries in various ways all over the world. Some countries' exports to the Gulf region have decreased. Others were unable to obtain remittances from their expatriates. Thousands of their people came back from the Gulf region, and only a handful could accommodate them. The majority of the countries have been altered by rising interest rates on old debts and new credit challenges. The rise in oil prices impacted a significant number of people. Both of these concerns, though, had a huge effect on Jordan (Van Hear, 1995).

According to Crown Prince Hassan, the Gulf War effect on Jordan can be divided into three categories: trade punitive measures contrary to Iraq, refugees fleeing the Gulf region who hurdled Jordan, and Jordanian emigrants who relocated to Jordan. Estimates on how much money would be lost due to the war varied at the time of the crisis, but they were thought to be enormous in Jordan. According to Mudhar Badran, Jordan's Prime Minister at the time, the nation's net loss was $\$ 8$ billion. According to Badran revealed that Jordan's exports to other Arab countries were $\$ 485.7$ million in 1989 and $\$ 42.8$ million in the first half of 1990, which was gradually declined after August 2, 1990, reaching zero at the end of 1990 and the first three months of 1991 (Van Hear,1995).

Bush's comment, according to the Los Angeles Times, was the first direct challenge to Jordan:

The Bush affirmation was the first overt warning of aggressive American intervention against an Arab country other than Iraq during the ongoing [Gulf] crisis. It showed the immense pressure placed on Middle Eastern countries to take sides in the 12-day-old war (Al Sarhan, 2016). Irrespective of these figures (particularly Badran's) a marketing ploy to acquire more foreign aids, the actual effect is tremendous, and Jordan's government was very concerned about the economy's future. Jordan's gross domestic product (GDP) dropped by more than $8 \%$, and the country's overall economic growth slowed, specifically in the first five months after the war. Jordan's overseas currency reserves and government incomes dropped, resulting in a \$308 million budget deficit in 1991, apart from interest payments. The recession impacted almost all manufacturing industries, resulting in a nearly $30 \%$ rise in unemployment and a $33 \%$ increases in poverty. Jordan was also forced to delay the implementation of the IMF reform program. In an article for al-Duster, Odeh Suleiman al-Swais consummated that, 
after the Iraqi and Kuwaiti economies, Jordan's economy agonized from the Kuwait crisis. Jordan's serious effect becomes clear as compared with other countries (Baram,1991).

As President Bush stated in a letter to the Senate, "Jordanian steadiness remains essential to the area and US interests - as well as to Israel's interests - and Jordan may play a substantial role in postwar diplomacy, mainly in the Arab-Israel peace process." The Senate agreed to resume assistance to Jordan on a provisional basis in response to Bush's letter since the President admitted and account to parliamentary boards on Jordan's success in proceeding with the Middle East reconciliation process. On the other hand, it would be restored if it could be shown that the intervention would benefit the Concord process. The President signed a waiver that allowed Jordan to collect all of the FY 1991 and FY 1992 aid contributions after signing the Jordanian-Israeli partnership agenda on September 17, 1993 (Al Sarhan, 2016). The rate of American aid to Jordan decreased during that war in 1991 (\$35 million), in 1992 (\$50 million) and 1993 (\$35 million), compared to the subsequent years in which JordanianAmerican relations would improve as a result of the signing of the Jordanian-Israeli Peace Treaty in In 1994, US aid to Jordan will return to what it was before the war, at a rate of one billion dollars annually

\section{Findings, Conclusion, and Recommendations}

This article provides a historical perspective of US foreign policy toward Jordan during the George H. W. Bush administration. It contains an analysis of how the important political and economic problems of that period affected relations between the United States and Jordan. Meanwhile, the Iraq war on Kuwait and Jordan's opposing the United States led to tension in the two sides' political and economic relations.

The study results reveal that The impact of the American foreign policy towards Jordan was a negative effect for a short period until the Madrid conference due to Jordan's anti-American stance. This influence emerged through economic aid and was not a security threat. The interests of the United States of America override those of its allies, and thus it sacrificed Jordan's interests to achieve its own interests. Therefore the negative impact was from the economic side, but the security side remained the same to maintain Jordan's stability. The Iraqi war on Kuwait led to a tense relationship between Jordan and the United States of America due to Jordan's refusal to enter the coalition against Iraq under the United States of America's leadership. The popular Jordanian position in Iraq's support in that war led to Jordanian pressure not to accept that alliance and this position. The United States of America has pressured the Gulf states to cut ties with Jordan.

Every political event has economic consequences, and due to the Jordanian political position towards that war, Jordanian relations with the Gulf countries were cut off due to American pressure. Also, oil supplies from Iraq, which were taken at symbolic prices, were cut off. Hundreds of thousands of expatriates in the Gulf countries returned to Jordan, also reduced American aid to Jordan and the closure of the port of Aqaba and a drop in the gross domestic product by $8 \%$, slowing economic growth, and an increase in the unemployment rate to $30 \%$ and poverty to $33 \%$.

The rate of American aid to Jordan decreased during that war in 1991 (\$35 million), in 1992 (\$50million) and 1993 (\$35 million), compared to the subsequent years in which JordanianAmerican relations would improve as a result of the signing of the Jordanian-Israeli Peace Treaty in In 1994, US aid to Jordan will return to what it was before the war, at a rate of one billion dollars annually. 
Based on the study results, the study recommends that Jordan build a network of alliances with powerful states and distrust one country. Self-reliance on the political and economic side to achieve political and economic development positively reflects Jordan. The interdependence should be mainly on the economic side so that a political dispute does not affect the economic relations between the two parties if any happens.

\section{References}

Al Sarhan, A. (2016). United States' Foreign Policy toward the Hashemite Kingdom of Jordan: 1990-2014.

Ashton, N. (2008). King Hussein of Jordan: A political life. Yale University Press.

Baram, A. (1991). Baathi Iraq and Hashimite Jordan: From Hostility to Alignment. Middle East Journal, 45(1), 51-70.

Berger, M. D. (1991). Implementing a United Nations Security Council Resolution: The President's Power to Use Force Without the Authorization of Congress. Hastings Int'I \& Comp. L. Rev., 15, 83.

Browne, M. A., \& Foreign Affairs, Defense, and Trade Division. (2003, March). The United Nations Security Council: Its Role in the Iraq Crisis: a Brief Overview. Congressional Research Service, Library of Congress.

Frantzman, S. (2010). Review of King Hussein of Jordan. Middle East Quarterly.

Mason, V. (2011). The im/mobilities of Iraqi refugees in Jordan: Pan-Arabism,'hospitality'and the figure of the 'refugee'. Mobilities, 6(3), 353-373.

O'Connell, M. E. (1990). Enforcing the Prohibition on the Use of Force: The UN's Response to Iraq's Invasion of Kuwait. S. III. ULJ, 15, 453.

Ryan, C. (2000). Between Iraq and a hard place: Jordanian-Iraqi relations. Middle East Report, (215), 40-42.

Sharp, J. M. (2015). Jordan: Background and U.S. Relations. Washington: Congressional Research Service.

Swaidan, Z., \& Nica, M. (2002). The 1991 Gulf war and Jordan's economy. Middle East, 6(2), 71.

Van Hear, N. (1995). The impact of the involuntary mass 'return'to Jordan in the wake of the Gulf crisis. International Migration Review, 29(2), 352-374. 